\title{
Invasive species in the soil seed bank of two limestone hills in Bogor, West Java, Indonesia
}

\author{
WINDA UTAMI PUTRI ${ }^{1, \boldsymbol{v}}$, IBNUL QAYIM ${ }^{2}$, ABDUL QADIR ${ }^{3}$ \\ ${ }^{1}$ Research Center for Plant Conservation and Botanic Gardens, Indonesian Institute of Sciences. Jl. Ir. Juanda No. 13 Bogor 16122, West Java, Indonesia. \\ Tel.: +62-251-8322187. ^email: winda.utami.putri@gmail.com \\ ${ }^{2}$ Department of Biology, Faculty of Mathematics and Natural Sciences, Institut Pertanian Bogor. Jl. Agatis, Kampus IPB Dramaga, Bogor 16680, West \\ Java, Indonesia \\ ${ }^{3}$ Department of Agronomy and Horticulture, Faculty of Agriculture, Institut Pertanian Bogor. Jl. Kamfer, Kampus IPB Dramaga, Bogor 16680, West \\ Java, Indonesia
}

Manuscript received: 7 May 2021. Revision accepted: 29 August 2021.

\begin{abstract}
Putri WU, Qayim I, Qadir A. 2021. Invasive species in the soil seed bank of two limestone hills in Bogor, West Java, Indonesia. Biodiversitas 22: 4019-4027. Study on the impact of invasive species on plant communities has been conducted mainly on the aboveground vegetation. The impact on the soil seed bank has received less attention mostly due to practical difficulties in conducting seed bank assessment. Evaluation of seed bank composition is useful in detecting invasive plant species that may have been present as buried seeds. Information on the vegetation composition in Nyungcung and Kapur hills both under and aboveground is available, but specific information on invasive species has not been discussed yet. This paper describes and analyzes the structure (composition and density) of invasive species in the soil seed bank. Eighty soil samples were taken from the study sites. The soil seed banks were analyzed using seedling emergence and seed extraction methods. 2602 and 1280 seedlings emerged from soil seed bank of Nyungcung and Kapur hills, respectively. From that number, approximately $48.96 \%$ and $68.51 \%$ of the seedlings are invasive species in the soil seed bank of Nyungcung and Kapur hills. The invasive species were dominants in the soil seed bank of the two sites. Cecropia peltata and Clidemia hirta were the most abundant invasive species in the Kapur and Nyungcung hills seed bank, respectively. Species richness and seedling density were higher in Nyungcung hills than Kapur hills, which were invaded for a relatively longer period.
\end{abstract}

Keywords: Belowground vegetation, germination, seedling

\section{INTRODUCTION}

Invasive species are known for their threat to biodiversity and ecosystem (Vilà et al. 2011; Pyšek et al. 2012; Bartz and Kowarik 2019) one of which is their contribution to the plant extinctions. Invasions are one of significant drivers of plant extinctions in biodiversity hotspots (Le Roux et al. 2019), and alien species are one of the top four threats associated with extinct species (Bellard et al. 2015). Invasive species can alter composition, functions and dynamic equilibrium of native community (Powell et al. 2011; Andreu and Vila 2011). The magnitude of impacts caused by alien species on native biota and human societies is increasing rapidly (van Kleunen et al. 2015). This increases research interest, which includes the process of invasive alien species influencing biodiversity and ecosystem functioning and the resulting impacts (Vilà et al. 2011; Gioria et al. 2012). Understanding the effects of invasive species on local species in an area can help to explain the effects of invasive species on populations, communities and the ecosystem as a whole. Most studies on the impact of invasive species on plant communities have been conducted mainly on the aboveground vegetation which describes only part of plant diversity in the community (Vilà and Gimeno 2007). Therefore, it could be incomplete to define a vegetation community based only on aboveground species composition, because there may be other species ready to emerge from the ground or dormant in the soil which are all incorporated in the soil seed bank (Faist et al. 2013; Li et al. 2017).

The soil seed bank (hereafter seed bank) is biodiversity reserve that consists of all viable seeds which exist on the surface or dormant in the soil and capable of producing physiologically independent individuals (de Andrade and Miranda 2014; Li et al. 2017). Study on the seed bank is important in understanding the implications of plant invasions because plant invasiveness is related to the high seed production which accumulates in the seed bank (Richardson and Kluge 2008). However, study on the impact of invasive species on seed banks has received less attention (Gioria et al. 2014) mostly due to the practical difficulties in conducting seed bank assessments (Gioria and Osborne 2009). Therefore, results of some studies may be able to describe the effect of invasive species on the existing vegetation at the time of the study but failed to describe the conditions in the past or predict the effects in the future.

Seed banks are known for their ability in maintaining a gene pool, which allows plants to continuously occupy a site after disturbance through a mechanism of regeneration in order to maintain floristic diversity (Shiferaw et al. 2018). With respect to invasion process, the seed bank promotes the successful establishment of alien species in new distribution ranges and support the persistence of alien 
species under unfavorable conditions for growth and development (Gioria et al. 2012; Pyšek et al. 2015; Gioria and Pyšek 2016; Gioria and Pyšek 2017). The capacity of alien species to form soil seed banks can contribute to their invasiveness and expansion (Gioria et al. 2012). Knowledge of species composition in the seed bank associated with plant invasions is essential in identifying the presence of invasive species at a locality (Richardson and Kluge 2008; Abella et al. 2012). The seed bank also provides "storage effect" (Chesson et al. 2013) which is a mechanism that allows the coexistence of species in a community associated with their specific response to changing environmental conditions and the use of resources. The storage effect is important for invasive species, because it may improve their capacity to respond to the conditions encountered in their alien range (Gioria et al. 2012, Long et al. 2015).

Limestone is a sedimentary rock formed principally of the minerals calcite and aragonite which have different crystal shapes of calcium carbonate $\left(\mathrm{CaCO}_{3}\right)$ (Britannica 2021). The rock is soluble in water but has good structural strength. When eroded, it can produce "karst" landscapes with their characteristic fissures, towers, and incredible cave systems (Smith 2021). Kapur and Nyungcung hills are part of Bojongmanik karst formation which steep rocky cliffs dominate areas. The physical condition of karst is unique both on the above and under the ground which encourages the unique types of plants and animals in the area. Activities in the study sites include forest production, ecotourism, and quarrying. Information on the composition of the aboveground vegetation and seed bank in both sites are available. The previous study in Kapur and Nyungcung hills detected the presence of invasive species in the aboveground of the sites but specific information on invasive species in the seed bank has not been discussed (Satyanti and Kusuma 2010; Widiyanti and Kusmana 2014).

In terms of the presence of invasive species in a plant community, evaluation of seed bank composition is useful in detecting invasive plant species that may have been present as buried seeds (Schneider et al. 2012). The impact of plant invasions on the seed bank in this study will be assessed on the basis of species composition, species richness (the number of species present in the seed bank), species abundance, and seed density (the number of seeds per square meter). Seed density and species richness are important factors for understanding soil seed banks (dos Santos et al. 2013). The composition and density of invasive species in the seed bank of Nyungcung and Kapur hills will also be described in this paper. The ultimate goal of this paper is to encourage the use of seed bank analysis in studies of invasive species.

\section{MATERIALS AND METHODS}

\section{Study sites}

This study was conducted in two sites, Nyungcung $\left(06^{\circ} 27^{\prime} 15.3^{\prime \prime} \mathrm{S}\right.$ and $\left.106^{\circ} 38^{\prime} 45.8^{\prime \prime} \mathrm{E}\right)$ and Kapur limestone hills $\left(06^{\circ} 32^{\prime} 59.8^{\prime \prime} \mathrm{S}\right.$ and $\left.106^{\circ} 41^{\prime} 16.1^{\prime \prime} \mathrm{E}\right)$ which located in Bogor District, West Java, Indonesia. Quarrying activity in both sites started around 1980s. The quarrying in Nyungcung hills was ended in 2005 while Kapur hills is still operating until the present time. Air temperature in Nyungcung hills is $27-35^{\circ} \mathrm{C}$, while in Kapur hills is relatively higher, $29-37^{\circ} \mathrm{C}$. Relative humidity in Nyungcung and Kapur hills was $49-78 \%$ and $53-70 \%$, respectively. The intensity of sunlight entering the stand of Kapur hills is relatively higher than Nyungcung hills. The light intensity was between $417-484 \times 10$ lux in Nyungcung hills and 1,816-1,823 ×10 lux in Kapur hills. The relatively lower temperatures, higher humidity levels, and light intensity in Nyungcung hills were presumably caused by better vegetation cover than Kapur hills. Average monthly rainfall in Nyungcung and Kapur hills were approximately $216.83 \pm 150.59 \mathrm{~mm}$ and $255.27 \pm 200.04 \mathrm{~mm}$, respectively.

The composition of plant species in Nyungcung and Kapur hills is relatively different. The vegetation in Nyungcung hills consisted mostly of Myrtaceae, Pandanaceae, Phyllanthaceae, Rubiaceae and Sapindaceae. Coffea liberica (Rubiaceae) dominated the site followed by Antidesma montanum (Phyllanthaceae), while Strophioblachia fimbricalyx (Euphorbiaceae), Stachytarpheta indica (Verbenaceae), Leucaena leucocephala (Leguminosae), and Calliandra calothyrsus (Leguminosae) were the dominant species in Kapur hills. The plants in Kapur hills mostly belong to Anacardiaceae, Euphorbiaceae, Leguminosae, Rutaceae, Sapindaceae, and Verbenaceae (Satyanti and Kusuma 2010; Widiyanti and Kusmana 2014).

\section{Seed bank assessment}

Forty soil samples were purposively taken from each site (a total of eighty soil samples from the two sites) using "small number of large samples" technique. Large soil sample sizes and sampled areas allow a relatively accurate determination of the presence and abundance of seeds of woody species in forest soils (Shen et al. 2014). The soil samples were collected using a $1 \mathrm{~m} \times 1 \mathrm{~m}$ quadratic plot with approximately $5-10 \mathrm{~cm}$ depth. Approximately 25.7$33.3 \%$ of seeds are active in the $0-5 \mathrm{~cm}$ soil layer since in that depth seeds effectively avoid the impact of insects, ants, birds, animals and other factors such as surface runoff and wind (Liu et al. 2019). During the field study, invasive species on the aboveground vegetation in the two hills were also recorded.

The seed bank assessment was conducted using seedling emergence and seed extraction methods. Seedling emergence method is widely used to estimate the soil seed bank because it can be used for large-scale studies and easily identify plant species (Erfanzadeh et al. 2020). The seedling emergence method provides data on species and seedling number of each species in the seed bank. Sixty soil samples were brought to the greenhouse and each were placed in a $44 \mathrm{~cm} \times 35 \mathrm{~cm} \times 10 \mathrm{~cm}$ plastic trays which were filled with $5-7 \mathrm{~cm}$ depth of sterilized sand. All emerging seedlings, including the invasive species, were identified in each tray, counted and removed on weekly basis. Species that could not be identified were grown until they could be identified. The process of identification and 
seedling counting was conducted until no germination had been observed in any of the trays for two consecutive weeks. The trial ran for approximately 10 months and was finished when emergence stopped.

Twenty soil samples were used in the seed extraction method. Soil samples were immersed in distilled water for 30 minutes and then gently stirred for 15-30 minutes. The mixture was left until the organic matter settled and then rinsed and filtered using a stratified filter $(1 \mathrm{~mm}$ and $5 \mathrm{~mm})$ to remove soil particles. Seeds were then air-dried, identified, and manually counted. Identification and counting process of small seeds were conducted under the microscope.

\section{Data analysis}

The data on the observed seedlings in each germination tray was presented in a description of the seed bank composition. Seedling density was calculated based on number of germinating seeds in all the observed germinating trays (express as the number of seedlings per tray). The number of each identified seed from seed extraction method was used to calculate the seed density (expressed as the number of seeds $\mathrm{m}^{-2}$ ) in the soil. Number of species and seedlings of invasive plants in each tray were recorded separately. The data on invasive species seedling numbers from each species were then used in calculating the invasive species seedling density. A t-test assessed differences of the seedlings and species number in the two study sites.

\section{RESULTS AND DISCUSSION}

\section{Seed bank composition}

During nine months, a total of 2602 seedlings emerged from the seed bank of Nyungcung hills. From the emerging seedlings, we identified 80 species in total, which belong to 41 families. Total species number was varied from 15 to 24 species per tray with an average of $18.13 \pm 2.42$ species per tray (Figure 1). Most of these species were Melastomataceae (45.16\%), Rubiaceae (12.95\%), and Primulaceae $(7.95 \%)$. The seed density was approximately $323.05 \pm 40.93$ seeds $\mathrm{m}^{-2}$. Total number of seedlings varied from 35 to 190 seedlings per tray with an average of $83.94 \pm 34.71$ seedlings per tray (Figure 2). The dominant species were Clidemia hirta, Melastoma malabathricum, and Mussaenda acuminata.

The seed bank of Kapur hills was composed of 50 species belonging to 29 families. Total species number varied from 7 to 16 species per tray with an average of $11.04 \pm 2.43$ species per tray (Figure 1). The species were mostly Urticaceae (50.94\%), Erythroxylaceae (5.94\%), and Verbenaceae $(5.70 \%)$. There were 1280 identified seedlings from Kapur hills seed bank. Seed density in Kapur hills was $210.24 \pm 40.88$ seeds $\mathrm{m}^{-2}$. The total number of seedlings varied from 13 to 181 seedlings per tray with an average of $45.71 \pm 39.29$ seedlings per tray (Fig 2). The dominant species were Cecropia peltata, Erythroxylum cuneatum, and Stachytarpheta indica. The t-test showed a statistically significant difference in seedling and species number between the two study sites $(\mathrm{p}<0.05)$.

\section{Invasive species in the seed bank}

We identified 17 invasive species from the seed bank of Nyungcung hills which belong to 12 families (Table 1). The number of invasive species was varied from two to six species per tray with an average of $3.87 \pm 1.18$ species per tray (Figure 1). Most of these species are Melastomataceae and Urticaceae. The number of identified invasive species from the seed bank was 1274 seedlings or approximately $48.96 \%$ of the total identified seedlings. Seedling number of invasive species varied from four to 70 seedlings per tray with an average of $39.00 \pm 20.46$ seedlings per tray (Figure 2). Melastomataceae was represented by $C$. hirta and M. malabathricum in Nyungcung hills and showed the highest seedling density, contributing approximately $22.63 \%$ and $22.52 \%$ to the total number of seedlings in the seed bank, respectively.

The seed bank in Kapur hills was composed of 12 invasive species which belong to ten families (Table 1). The number of invasive species varied from two to seven species per tray with an average of $4.18 \pm 1.12$ species per tray (Figure 1). The species were mostly Urticaceae and Melastomataceae. There were 877 seedlings of identified invasive species or approximately $68.51 \%$ of the total identified seedlings in the seed bank of Kapur hills. Seedling number of invasive species varied from two to 168 seedlings per tray with an average of $31.36 \pm 28.46$ seedlings per tray (Figure 2). The abundant invasive species were Cecropia peltata and Stachytarpheta indica. Being represented by only one species, Urticaceae showed the highest seedling density in the seed bank of Kapur hills, mainly because of the high seed density of $C$. peltata which contributed approximately $50.47 \%$ of the viable seeds found in the seed bank.

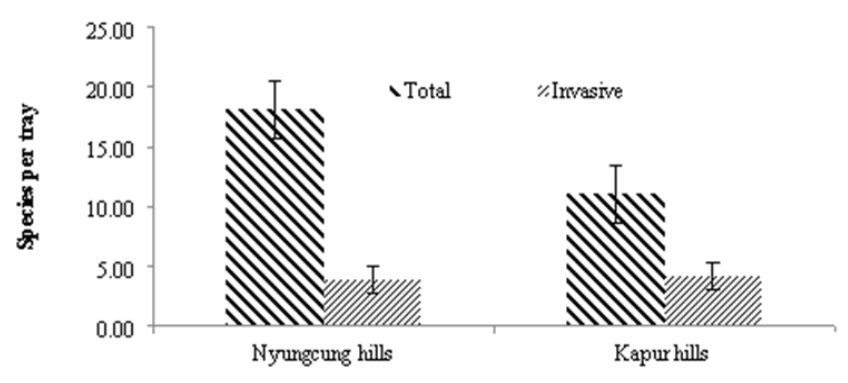

Figure 1. Number of species per-tray in the seed bank of Nyungcung and Kapur hills, Bogor, Indonesia

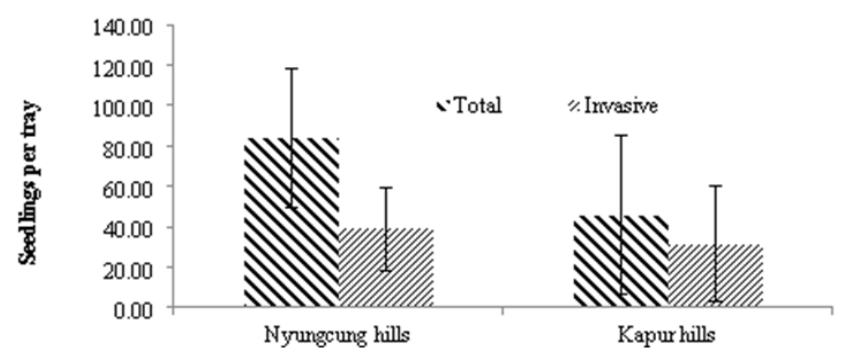

Figure 2. Number of seedlings per tray in the seed bank of Nyungcung and Kapur hills, Bogor, Indonesia 
The seedling density of each species (Table 2) was calculated based on the number of invasive species and total seedlings present in each tray. Species with a relatively high seedling density in Nyungcung hills were $C$. hirta and M. malabathricum while in Kapur hills it was $C$. peltata. Number of seedlings of $C$. hirta ranged from one to

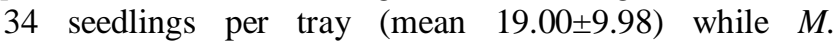
malabathricum ranged from one to 44 seedlings per tray (mean 19.13 \pm 12.70 ) and C. peltata ranged from one to 132 seedlings per tray (mean 25.84 \pm 34.56 ).
There were 19 invasive species recorded in the two sites, 10 species were common to both sites (Table 2). Among these 10 taxa, there were two species that were relatively abundant in the two hills. They were Cecropia peltata and Clidemia hirta. Seven species were present in Nyungcung but absent in Kapur hills, while only two were present in Kapur hills but absent in Nyungcung hills. The two sites have $52.63 \%$ similarity in their invasive species composition. Based on the t-test, there was no statistically significant difference between the two study sites' seedling and species number of the invasive species ( $p>0.05)$.

Table 1. Number of invasive species seedlings in the seed bank of Nyungcung and Kapur hills, Bogor, Indonesia

\begin{tabular}{|c|c|c|c|}
\hline \multirow{2}{*}{ Species } & \multirow{2}{*}{ Family } & \multicolumn{2}{|c|}{ Number of seedlings } \\
\hline & & Nyungcung & Kapur \\
\hline Abrus precatorius $\mathrm{L}$. & Leguminosae & 1 & - \\
\hline Ageratum conyzoides (L.) L. & Compositae & 1 & - \\
\hline Calliandra calothyrsus Meisn. & Leguminosae & - & 1 \\
\hline Cecropia peltata $\mathrm{L}$. & Urticaceae & 44 & 646 \\
\hline Chromolaena odorata (L.) R.M. King \& H. Rob. & Compositae & 13 & 14 \\
\hline Clidemia hirta (L.) D. Don. & Melastomataceae & 589 & 40 \\
\hline Cyperus rotundus $\mathrm{L}$. & Cyperaceae & 6 & - \\
\hline Hibiscus macrophyllus Roxb. ex Hornem. & Malvaceae & 11 & 9 \\
\hline Hiptage benghalensis (L.) Kurz & Malpighiaceae & 1 & 9 \\
\hline Lantana camara $\mathrm{L}$. & Verbenaceae & 5 & - \\
\hline Leucaena leucocephala (Lam.) de Wit & Leguminosae & - & 7 \\
\hline Melastoma malabathricum $\mathrm{L}$. & Melastomataceae & 586 & - \\
\hline Mikania micrantha Kunth & Compositae & 7 & 6 \\
\hline Momordica charantia $\mathrm{L}$. & Cucurbitaceae & 1 & - \\
\hline Oxalis corniculate $\mathrm{L}$. & Oxalidaceae & 2 & 2 \\
\hline Passiflora foetida $\mathrm{L}$. & Passifloraceae & 1 & 1 \\
\hline Piper aduncum L. & Piperaceae & 3 & 69 \\
\hline Sida rhombifolia $\mathrm{L}$. & Malvaceae & 1 & - \\
\hline Stachytarpheta indica (L.) Vahl & Verbenaceae & 2 & 73 \\
\hline
\end{tabular}

Table 2. Seedling density of invasive species in the seed bank of Nyungcung and Kapur hills, Bogor, Indonesia

\begin{tabular}{|c|c|c|c|}
\hline \multirow[t]{2}{*}{ Species } & \multirow[t]{2}{*}{ Family } & \multicolumn{2}{|c|}{ Seedling density } \\
\hline & & Nyungcung & Kapur \\
\hline Abrus precatorius L. & Leguminosae & 0.03 & - \\
\hline Ageratum conyzoides (L.) L. & Compositae & 0.03 & - \\
\hline Calliandra calothyrsus Meisn. & Leguminosae & - & 0.04 \\
\hline Cecropia peltata $\mathrm{L}$. & Urticaceae & 1.42 & 23.07 \\
\hline Chromolaena odorata (L.) R.M.King \& H.Rob. & Compositae & 0.42 & 0.50 \\
\hline Clidemia hirta (L.) D. Don. & Melastomataceae & 19.00 & 1.43 \\
\hline Cyperus rotundus $\mathrm{L}$. & Cyperaceae & 0.19 & - \\
\hline Hibiscus macrophyllus Roxb. ex Hornem. & Malvaceae & 0.35 & 0.32 \\
\hline Hiptage benghalensis (L.) Kurz & Malpighiaceae & 0.03 & 0.32 \\
\hline Lantana camara $\mathrm{L}$. & Verbenaceae & 0.16 & - \\
\hline Leucaena leucocephala (Lam.) de Wit & Leguminosae & - & 0.25 \\
\hline Melastoma malabathricum L. & Melastomataceae & 18.90 & - \\
\hline Mikania micrantha Kunth & Compositae & 0.23 & 0.21 \\
\hline Momordica charantia $\mathrm{L}$. & Cucurbitaceae & 0.03 & - \\
\hline Oxalis corniculate L. & Oxalidaceae & 0.06 & 0.07 \\
\hline Passiflora foetida $\mathrm{L}$. & Passifloraceae & 0.03 & 0.04 \\
\hline Piper aduncum L. & Piperaceae & 0.10 & 2.46 \\
\hline Sida rhombifolia $\mathrm{L}$. & Malvaceae & 0.03 & - \\
\hline Stachytarpheta indica (L.) Vahl & Verbenaceae & 0.06 & 2.61 \\
\hline
\end{tabular}




\section{Discussion}

Species richness represented by the number of species present in the seed bank of the two sites was relatively high. The number was relatively similar to the results of $\mathrm{He}$ et al. (2020) obtained in Guiyang karst landscape in China which had approximately 89 species. The number of species in Nyungcung is higher than Kapur hills. This can also be seen from the number of species recorded in each observed tray from the two sites. The average number of species per tray from Nyungcung soil samples was approximately $18.13 \pm 2.42$ species. This value was relatively higher than the Kapur sample which was approximately $11.04 \pm 2.43$ species. Mean values of the species number in the two sites were significantly different. The difference in the number of species is most likely associated with a relatively higher level of disturbance in Kapur hills. Intense and prolong quarrying activity could reduce the number of species on the site. The presence of a relatively higher number of invasive species in the Kapur hills might also cause the lower number of species in the area. Invasive alien species are one of potential threats to native plant diversity (Corlett 2016). The species can have massive local impacts, reducing native plant diversity, and changing fire regimes and nutrient cycling (Vilà et al. 2011; Pyšek et al. 2012).

Seed density in both study sites is relatively low. The figure is relatively similar to the seed bank density of a highly disturbed forest in Northeastern Thailand which is approximately $331 \pm 51.97$ seeds $\mathrm{m}^{-2}$ (Chalermsri et al. 2020). Seeds in the disturbed forest in the Chalermsri et al. (2020) study experiencing seed limitation events, including limitation in number of seeds (source limitation) and limitation in the dispersal of available seeds (dispersal limitation) due to bamboo co-domination in the forest, while in Nyuncung and Kapur, the hilly area of the sites caused the seeds to be carried away by surface runoff and stays in the hill basins which caused low storage of seeds in the seed bank particularly in Kapur hills. These limitations could help to explain the relatively low density and the similarity of the seed bank density in Nyungcung, Kapur, and the disturbed forest in Northeastern Thailand. Seed density reflects the amount of seed rain that entered the area from the dispersal of seeds both from the aboveground vegetation and from nearby vegetation (Rungrojtrakool 2021). According to Lippok et al. (2013), seed density is positively related to species richness; this is in line with our results where species richness and seed density in Nyungcung soil was relatively higher than Kapur soil. Compared with forest areas that have been restored, the seed density in the two observed sites is relatively low. The Shilin Stone Forest in Yunnan, China is a forested karst area with seed density of approximately 3198 seeds $\mathrm{m}^{-2}$. The Shilin Stone Forest was restored through conservation efforts after has been severely disturbed in the previous decades (Shen et al. 2007). Level of disturbance that causes reduction in vegetation may explain these differences. The level of disturbance affects the vegetation composition, which ultimately affects the seed density in the soil. Nyungcung and Kapur hills have been disturbed by quarrying activity for more than 30 years and have lost approximately $50 \%$ of their forested area.

Based on the observations, the number of seedlings growing from Nyungcung soil samples was relatively higher than the Kapur soil samples. This finding is in line with the amount of seedling growing in each tray from each soil sample. This condition is potentially caused by the relatively shallower slope in Nyungcung hills compared to the slope in Kapur hills. Shallow slope allowed most of the seeds to be stored and avoid being carried away by surface runoff. In their study, Martinez-Duro et al. (2012) found that increasing slope had a negative effect on total diversity and density, highlighting the relevance of runoff processes as a key factor in the seed dispersal in the soil. Run-off may, therefore, affect seed density (number of seedlings per tray) and total seed richness (number of species). Apart from slope condition, another parameter that affects the higher number of seedlings in Nyungcung is the relatively higher number of species in the site than in Kapur hills.

Plant community composition dominated by shrubs and herbs in the limestone karst ecosystem is common. Species like C. hirta, M. malabathricum, M. acuminata, E. ribes, and $C$. pubescens were among shrubs and herbs that were abundant in the seed bank of Nyungcung hills with $C$. hirta being the most abundant. While in Kapur hills, C. peltata was the most abundant followed by $P$. aduncum and $C$. hirta. Most of these abundant species are invasive plants. In the aboveground vegetation in Nyungcung hills, several invasive species were $C$. peltata, $H$. benghalensis, $L$. camara, $P$. aduncum, and $S$. indica. While in Kapur hills, the species include $C$. calothyrsus, $H$. benghalensis, $P$. aduncum, and $S$. indica. All of these species were present in the seed bank but not all of the species in the seed bank were present in the aboveground vegetation. The composition dissimilarity of the aboveground vegetation and the seed bank found in many studies indicates that certain number of seed bank diversity is not represented in the aboveground; therefore seed bank species pools did not closely resemble the standing vegetation (Grewell et al. 2019; He et al. 2020). The high abundance of "new species" which is not yet widespread in the aboveground, often occurs because the "new species" seeds were already present in the seed bank, and become a source of recruitment under favorable conditions (Vandvik et al. 2016). The presence of species in the soil seed banks is affected not only by the aboveground vegetation but also by dispersal mechanism (Rungrojtrakool 2021), which explains why the seed bank in the two study sites was not reflected in the aboveground vegetation. This finding is in line with experiments conducted by $\mathrm{He}$ et al. (2020) on seed bank in a karst landscape in central Guizhou Province, China.

In disturbed sites like Nyungcung and Kapur hills, the presence of invasive species in seed banks, including the dominance of some, is a common finding (Gioria et al. 2011). These species initially grew in the study sites and formed a seed bank, but later the adult plant cannot survive due to unfavorable environmental condition, while the seeds in the seed bank are able to tolerate or escape the unfavorable condition (Gioria et al. 2014), maintain their 
viability, and germinate. Secondary seed dispersal from another area may also explain the presence of certain invasive species in the soils either naturally or through anthropogenic activities. A recent study by van Kleunen et al. (2015) showed that approximately 13,168 species or $3.9 \%$ of the world's vascular plant flora have become naturalized somewhere outside their native range as a result of human activities. Invasion of organism itself is a sequence of events involving the transport, introduction, establishment, and spread of organisms into a new region through natural dispersal or, far more frequently by human activities across a geographic barrier (Ricciardi 2013) which are intentionally or unintentionally. Therefore, the distribution of many invasive species is highly related to humans, one of which occurred in the study sites. Quarrying process caused the transfer of soil volume during the limestone extraction. Species with a large number of small seeds stored in the seed bank are presumably able to adapt to this type of distribution.

Generally, the seeds of invasive species are relatively small in size, therefore the seeds dispersal of these species is very effective and that allows them to spread over large areas (McIntyre et al. 2005). In their study, Gao et al. (2018) shows that most invasive plants in their study produce a large number of small seeds. This is consistent with the results of observations on invasive species seeds in the study sites. The seed size is relatively small (Figure 3) and the number is relatively large. Seed size is correlated with seed persistence in the soil where small and rounded seeds tended to persist for long period of time in the soil (Kalamees et al. 2012, Long et al. 2015). Seed persistence allows plants to disperse their seeds through time and to avoid germination in unfavorable conditions (Ooi 2012). This could partly explain the presence of an invasive species in the seed bank even when the adult plant was not present in the aboveground vegetation.

The invasive species number in Nyungcung and Kapur hills were approximately $21.25 \%$ and $24 \%$ of the total species in the seed bank, respectively. There was no significant difference between Nyungcung and Kapur hills in terms of species number. The number of species is relatively low, but the seedling number is the opposite. The invasive species seedlings were present in abundant number in the seed bank. The invasive species seedlings cover almost $50 \%$ of the total seedlings in Nyungcung and $70 \%$ in Kapur seed bank. Analysis conducted by Gioria and Pyšek (2016) on published studies on invaded seed banks shows that when the seeds of the invader under investigation are included, native seeds represent less than $50 \%$ of the seeds in invaded seed banks at the majority of invaded sites. High seed production and capacity to germinate under a broad range of environmental conditions are traits that distinguish invasive species from other plants species which are non-invasive (Gioria and Pyšek 2017; Gioria et al. 2018), could explain their dominance in the two study sites. Implications that may arise from a high percentage of invasive species in the seed bank are rapid dominance of the species in the aboveground vegetation and the displacement of native species in the site.

The density of several invasive species present in the two sites shows that species in Kapur hills have a relatively higher density than in Nyungcung hills. In both study sites, C. peltata was present with a relatively high density in the soil. Cecropia peltata seedling density in Kapur hills was higher 17 times than in Nyuncung hills. Strydom et al. (2012) stated that the higher number of seeds in the seed bank under long-invaded areas can be explained by the higher number of seed rain events from trees that had been in the area for a longer period. Several studies have shown that in some areas, seed density is much higher in long invaded sites compared with recently invaded sites. This is in line with longer periods and higher levels of disturbance in Kapur compared to Nyungcung hills.

Herrera et al. (2011) reported that seedling density of a certain invasive species in an invaded area is larger compared to its native region. The seedling density of $C$. peltata in Nyungcung and Kapur hills was approximately 1.47 seedlings $\mathrm{m}^{-2}$ and 21.53 seedlings $\mathrm{m}^{-2}$, respectively. The number is 61 to 900 times larger than the seedling density in a tropical forest in Costa Rica which was native region of $C$. peltata. Fleming and Williams (1990) reported that in tree-covered transect on a roadside of Santa Rosa National Park, Costa Rica there were 191 seedlings at a density of 239 seedlings ha ${ }^{-1}$. This shows that in areas outside of their native region, the invasive species are able to produce larger quantities of seed. This is one of the strategies of this species to survive outside their native region and invade the area.

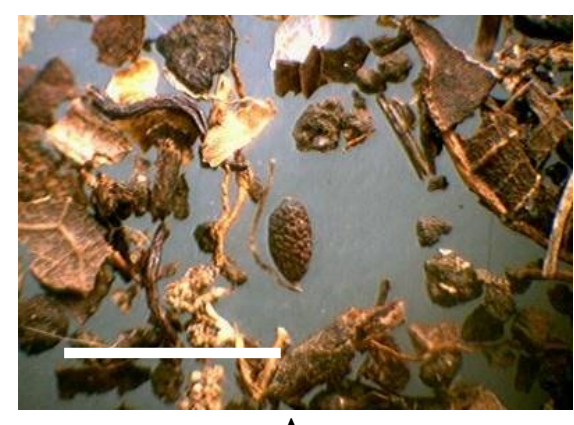

A

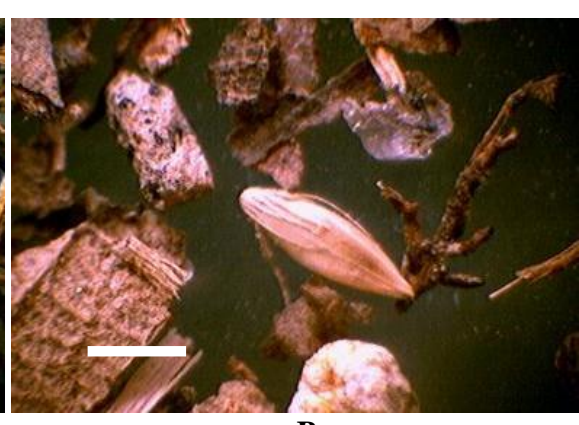

B

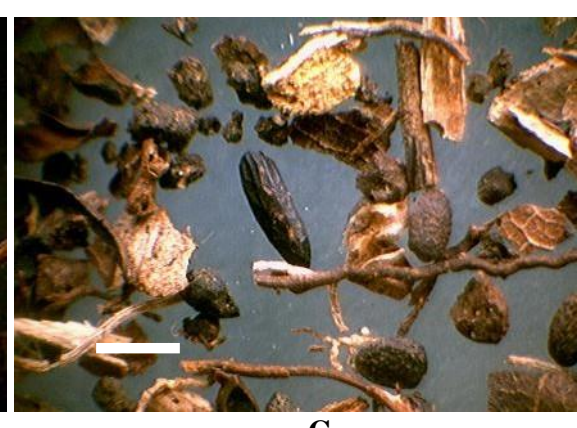

C

Figure 3. Seed size of: A. Mikania micrantha; B. Stachytarpheta indica; C. Cecropia peltata. Bar $=2 \mathrm{~mm}$ 
From a relatively small number of species, the invasive species were able to dominate in the seed bank. The disproportionately high seedling density of invasive species in both sites reflects competitive growth and high seed production of the species, which is in line with Goets et al. (2018) findings in their studies. The invasive species in both sites were able to incorporate a large number of seeds into the seed bank which according to Gioria and Pyšek (2017) is a strategy for ensuring the persistence of the species. Several studies show that successful invasive plants have large persistent seed banks (Gioria et al. 2012). This success is also supported by the fact that any natural or anthropogenic disturbance can easily trigger seed germination of invasive species (Gioria and Osborne 2009). The combination of disturbance, large production of seeds, and seed viability are factors that promote the future dominance of invasive species.

Plant invaders have the ability to change both transient and persistent components of the seed bank (Gioria and Osborne 2010) but in the short term, they are likely to affect the transient component of the seed bank as shown by the results of this study. Seed germination in this study occurred immediately after sowing and seeds were successfully germinated for a period of less than one year. Therefore, the seed bank assessed in this study could be classified as transient. Most of the seeds that were successfully germinated are orthodox seeds. Several invasive species with orthodox seeds present in the two study sites were $P$. aduncum, $C$. hirta, and $C$. peltata. The seed viability of $P$. aduncum in the soil can last up to approximately four months (Rogers and Hartemik 2000) while $C$. hirta can stay viable in the soil and develop a seed bank that persists for four years (CABI 2021). Cecropia peltata seeds can remain viable for up to six months in storage (Silander and Lugo 1990). This species forms seed bank in the soil which lasts more than five years (Webber et al. 2011). The type of C. peltata seed bank is suspected to be pseudo persistent which is indicated by its ability to maintain a persistent soil seed bank, although individual seeds are not persistent. The seedling number of $C$. peltata covers approximately $50 \%$ of the total seedlings in Nyungcung soil. The invasiveness of a species under certain environmental conditions can be seen through the ability to dominate the seed bank of invaded communities (Gioria and Osborne 2010) just like the dominance showed by $C$. peltata in Kapur hills seed bank.

Results of this study are central to the development of effective conservation, management and control strategies of the invasive species in the sites. Abbas et al. (2021) study highlights the importance of evaluating seed banks when making invasive species management decisions. Through this study, we are able to identify the invasive species present in the seed bank and analyze their composition and density.

In conclusion, species richness and seedling density were higher in Nyungcung hills than Kapur hills, which were invaded for a relatively longer period. Invasive species numbers in the seed bank of Nyungcung and Kapur hills were relatively low but the seedling number and densities were relatively high. The presence of invasive species in the sites has caused the seed bank dominated by their seeds. Cecropia peltata and C. hirta were the most abundant invasive species and had a relatively high density compared to other invasive species in the Kapur and Nyungcung hills seed bank, respectively. The degree of disturbance that occurs is presumably to have different levels of effect on the composition and seed density in the seed bank of the two sites. This study shows that information on seed banks is necessary to develop a strategy on invasive plant management and ecosystem restoration through natural revegetation. If the density of persistent seeds of native species in the soil seed bank is sufficient, successful restoration might still be possible (Kalamees et al. 2012).

\section{ACKNOWLEDGEMENTS}

This study was funded by the Indonesia Endowment Fund for Education, Ministry of Finance of The Republic of Indonesia. We are thankful for all the supports from Bogor Agricultural University and Kebun Raya Bogor. We would like to send our gratitude to Johan Apriandi and Aswar Rustam for their contribution to the fieldwork and Harto for his assistance in the fieldwork and plant (including seeds and seedlings) identification.

\section{REFERENCES}

Abbas AM, Pickart AJ, Goldsmith LM, Davenport DN, Newby Britney, Muñoz-Rodríguez AF, Grewell BJ, Castillo JM. 2021. Seed bank persistence of a South American cordgrass. AoB PLANTS 13 (3): 111. DOI: 10.1093/aobpla/plab014.

Abella SR, Chiquoine LP, Backer DM. 2012. Ecological characteristics of sites invaded by buffelgrass (Pennisetum ciliare). Invasive Plant Sci Manag 5 (4): 443-453. DOI: 10.1614/IPSM-D-12-00012.1.

Andreu J, Villa M. 2011. Native plant community response to alien plant inversion and removal. Manag Biol Inversion 2: 81-94. DOI: 10.3391/mbi.2011.2.1.08.

Bartz R, Kowarik I. 2019. Assessing the environmental impacts of invasive alien plants: a review of assessment approaches. NeoBiota 43: 69-99. DOI: 10.3897/neobiota.43.30122.

Bellard C, Cassey P, Blackburn TM. 2016 Alien species as a driver of recent extinctions. Biol Lett 12: 20150623. DOI: $10.1098 / \mathrm{rsbl} .2015 .0623$.

Britannica. 2021. Limestone. Encyclopedia Britannica. https://www.britannica.com/science/limestone.

CABI. 2021. Invasive species compendium-Clidemia hirta. https://www.cabi.org/isc/datasheet/13934.

Chalermsri A, Ampornpan L, Purahong W. 2020. Seed rain, soil seed bank, and seedling emergence indicate limited potential for selfrecovery in a highly disturbed, tropical, mixed deciduous forest. Plants 9 (10): 1391. DOI: 10.3390/plants9101391.

Chesson P, Huntly NJ, Roxburgh SH, Pantastico-Caldas M, Facelli JM. 2013. The storage effect: definition and tests in two plant communities. In: Kelly CK, Bowler MG, Fox GA (eds) Temporal Dynamics and Ecological Process. Cambridge University Press, UK.

Corlett RT. 2016. Plant diversity in a changing world: status, trends, and conservation needs. Plant Diver 38 (1): 10-16. DOI: 10.1016/j.pld.2016.01.001.

de Andrade LAZ, Miranda HS. 2014. The dynamics of the soil seed bank after a fire event in a woody savanna in central Brazil. Plant Ecol 215 (10): 1199-1209. DOI: 10.1007/s11258-014-0378-z.

dos Santos DM, da Silva KA, de Albuquerque UP, dos Santos JMFF, Lopes CGR, Araújo EdL. 2013. Can spatial variation and inter-annual variation in precipitation explain the seed density and species richness of the germinable soil seed bank in a tropical dry forest in north- 
eastern Brazil? Flora-Morphol Distrib Func Ecol Plants 208 (7): 445452. DOI: $10.1016 /$ j.flora.2013.07.006.

Erfanzadeh R, Shayesteh Palaye AA, Ghelichnia H. 2020. Shrub effects on germinable soil seed bank in overgrazed rangelands. Plant Ecol Diver 13 (2): 199-208. DOI: 10.1080/17550 874.2020.17182 33.

Faist AM, Ferrenberg S, Collinge SK. 2013. Banking on the past: seed banks as a reservoir for rare and native species in restored vernal pools. AoB Plants 5: 1-11. DOI: 10.1093/aobpla/plt043.

Fleming TH, Williams CF. 1990. Phenology, seed dispersal, anc recruitment Cecropia peltata (Moraceae) in Costa Rican tropical dry $\begin{array}{llllll}\text { forest. J Trop Ecol } 6 & \text { (2): 163-178. DOI }\end{array}$ $10.1017 /$ S0266467400004260.

Gao L, Hou B, Cai ML, Zhai JJ, Li WH, Peng CL. 2018. General laws of biological invasion based on the sampling of invasive plants in China and the United States. Glob Ecol Conserv 16: e00448. DOI 10.1016/j.gecco.2018.e00448 2351-9894.

Gioria M, Dieterich B, Osborne B. 2011. Battle of the giants: Primary and secondary invasions by large herbaceous species. Biology and Environment: Proceedings of the Royal Irish Academy 111 (3): 1.

Gioria M, Jarošík V, Pyšek P. 2014. Impact of invasions by alien plants on soil seed bank communities: Emerging patterns. Perspect Plant Ecol Evol Sys 16 (3): 132-142. DOI: 10.1016/j.ppees.2014.03.003

Gioria M, Osborne BA. 2009. Assessing the impact of plant invasions on soil seed bank communities: Use of univariate and multivariate statistical approaches. J Veg Sci 16 (3): 132-142. DOI 10.1111/j.1654-1103.2009.01054.x.

Gioria M, Osborne BA. 2010. Similarities in the impact of three large invasive plant species on soil seed bank communities. Biol Invasions 12: 1671-1683. DOI: 10.1007/s10530-009-9580-7.

Gioria M, Pyšek P, Moravcova L. 2012. Soil seed banks in plant invasions: Promoting species invasiveness and long-term impact on plant community dynamics. Preslia 84 (2): 327-350.

Gioria M, Pyšek P, Osborne BA. 2018. Timing is everything: does early and late germination favor invasions by herbaceous alien plants? J Plant Ecol 11 (1): 4-16. DOI: 10.1093/jpe/rtw105.

Gioria M, Pyšek P. 2016. The legacy of plant invasions: changes in the soil seed bank of invaded plant communities. Bioscience 66 (1): 40 53. DOI: $10.1093 /$ biosci/biv165.

Gioria M, Pyšek P. 2017. Early bird catches the worm: germination as a critical step in plant invasion. Biol Invasions 19 (4): 1055-1080. DOI 10.1007/s10530-016-1349-1.

Goets SA, Kraaij T, Little KM. 2018. Seed bank and growth comparisons of native (Virgilia divaricata) and invasive alien (Acacia mearnsi and A. melanoxylon) plants: implications for conservation. PeerJ 6: e5466. DOI: $10.7717 /$ peerj.5466.

Grewell BJ, Gillard MB, Futrell CJ, Castillo JM. 2019. Seedling emergence from seed banks in Ludwigia hexapetala-invaded wetlands: Implications for restoration. Plants 8 (11): 451. DOI: 10.3390/plants8110451.

He X, Yuan L, Wang ZH, Zhou Z, Wan L. 2020. A study of soil seed banks across one complete chronosequence of secondary succession in a karst landscape. PeerJ 8: e10226. DOI: 10.7717/peerj.10226.

Herrera AM, Carruthers RI, Mills NJ. 2011. Introduced populations of Genista monspessulana (French broom) are more dense and produce a greater seed rain in California, USA, than native populations in the Mediterranean Basin of Europe. Biol Invasions 13: 369-380. DOI:10.1007/s10530-010-9829-1.

Kalamees R, Pussa K, Zobel K, Zobel M. 2012. Restoration potential of the persistent soil seed bank in successional calcareous (alvar) grasslands in Estonia. App Veg Sci 15 (2): 208-218 DOI:10.1111/j.1654-109X.2011.01169.x.

Le Roux JJ, Hui C, Castillo ML, Iriondo JM, Keet JH, Khapugin AA, Medail F, Rejmanek M, Theron G, Yannelli FA, Hirsch H. 2019 Recent anthropogenic plant extinctions differ in biodiversity hotspots and coldspots. Curr Biol 29 (17): 2912-2918. DOI 10.1016/j.cub.2019.07.063

Li CD, Xiao B, Wang Q, Zheng R, Wu J. 2017. Responses of seed bank and Vegetation to the Increasing Intensity of Human Disturbance in a Semi-Arid Region of Northern China. Sustainability 9 (10): 1837 DOI: $10.3390 / \mathrm{su} 9101837$.

Lippok D, Walter F, Hensen I, Beck SG, Schleuning M. 2013. Effects of disturbance and altitude on soil seed banks of tropical montane $\begin{array}{llllll}\text { forests. J Trop Ecol } 29 & \text { (06): 523-529. DOI: }\end{array}$ 10.1017/S0266467413000667

Liu X, He Y, Xiao Y, Wang Y, Jiang Y, Jiang Y. 2019. Soil seed burial and competition with surrounding plants determine the emergence and development of seedlings of an endangered species Horsfieldia hainanensis Merr. in China. Sci Rep 9 (1): 1-8. DOI: 10.1038/s41598-019-54644-7.

Long RL, Gorecki MJ, Renton M, Scott JK, Colville L, Goggin DE, Commander LE, Westcott DA, Cherry H, Finch-Savage WE. 2015. The ecophysiology of seed persistence: a mechanistic view of the journey to germination or demise. Biol Rev 90 (1): 31-59. DOI: 10.1111/brv.12095

Martinez-Duro E, Luzuriaga AL. Ferrandis P, Escudero A, Herranz JM. 2012. Does aboveground vegetation composition resemble soil seed bank during succession in specialized vegetation on gypsum soil? Ecol Res 27 (1): 43-51. DOI: 10.1007/s11284-011-0870-z.

McIntyre S, Martin TG, Heard KM, Kinloch J. 2005. Plant traits predict impact of invading species: an analysis of herbaceous vegetation in the subtropics. Aust J Bot 53 (8): 757-770. DOI: 10.1071/BT05088.

Ooi MKJ. 2012. Seed bank persistence and climate change. Seed Sci Res 22 (S1): S53-S60. DOI: 10.1017/S0960258511000407.

Powell KI, Chase JM, Knight TM. 2011. A synthesis of plant invasion effects on biodiversity across spatial scales. Am J Bot 98 (3): 539548. DOI: $10.3732 /$ ajb. 1000402

Pyšek P, Jarošík V, Hulme PE, Pergl J, Hejda M, Schaffner U, Vilà M. 2012. A global assessment of alien invasive plant impacts on resident species, communities and ecosystems: the interaction of impact measures, invading species' traits and environment. Glob Change Biol 18 (5): 1725-1737. DOI: 10.1111/j.1365-2486.2011.02636.x.

Pyšek P, Manceur AM, Alba C, McGregor K, Pergl J, S - tajerova', K, Chytry' M, Danihelka J, Kartesz J, Klimešova' J, Lučanova' M, Moravcova' L, Nishino M, Sa dlo J, Suda J, Tichy’ L, Ku“hn I. 2015. Naturalization of central European plant species in North America: species traits habitats propagule pressure residence time. Ecology 96 (3): $145-157$. DOI: $10.1890 / 14-1005.1$.

Ricciardi A. 2013. Invasive Species. In: Leemans R (ed) Ecological Systems: Selected Entries from the Encyclopedia of Sustainability Science and Technology. Springer Science and Business Media New York, USA. DOI 10.1007/978-1-4614-5755-8_10.

Richardson DM, Kluge RL. 2008. Seed banks of invasive Australian Acacia species in South Africa: Role in invasiveness and options for management. Pers Plant Ecol Evol Sys 10: 161-177. DOI: 10.1016/j.ppees.2008.03.001

Rogers HM, Hartemink AE. 2000. Soil seed bank and growth rates of an invasive species, Piper aduncum, in the lowlands of Papua New Guinea. J Trop Ecol 16: 243-51. DOI: 10.1111/wre.12134.

Rungrojtrakool P, Tiansawat P, Jampeetong A, Shannon DP, Chairuangsri S. 2021. Soil seed banks of tree species from natural forests, restoration sites, and abandoned areas in Chiang Mai, Thailand. For Soc 5(1): 167-180 DOI: 10.24259/fs.v5i1.11612.

Satyanti A, Kusuma YWC. 2010. Ecological study in two quarried limestone karst hills in Bogor West Java: vegetation structure and floristic composition. Biotropia 17 (2): 115-129. DOI: 10.11598/btb.2010.17.2.81

Schneider HE, Allen EB. 2012. Effects of elevated nitrogen and exotic plant invasion on soil seed bank composition in Joshua Tree National Park. Plant Ecol 213 (8): 1277-1287. DOI: 10.1007/s11258-0120085-6.

Shen Y, Liu W, Cao M, Li Y. 2007. Seasonal variation in density and species richness of soil seed banks in karst forest and degraded vegetation in central Yunnan, SW China. Seed Sci Res 17 (2): 99107. DOI: $10.1017 / \mathrm{S} 0960258507708139$.

Shen Y, Liu W, Li Y, Guan H. 2014. Large sample area and size are needed for forest soil seed bank studies to ensure low discrepancy with standing vegetation. PLoS One 9 (8): 1-8. DOI: 10.1371/journal.pone.0105235. DOI: 10.1371/journal.pone.0105235.

Shiferaw W, Demissew S, Bekele T. 2018. Ecology of soil seed banks: Implications for conservation and restoration of natural vegetation: A review. Intl J Biodivers Conserv 10 (10): 380-393. DOI: 10.5897/IJBC2018.1226.

Silander SR, Lugo AE. 1990. Cecropia peltata L. Yagrumo hembra, Trumpet-tree.

https://www.srs.fs.usda.gov/pubs/misc/ag_654/volume_2/cecropia/pel tata.htm.

$\begin{array}{llll}\text { Smith } & \text { T. } & 2021 . & \text { Limestone }\end{array}$ https://www.tobysmith.com/project/limestone-karst/.

Strydom M, Esler KJ, Wood AR. 2012. Acacia saligna seed banks: Sampling methods and dynamics, Western Cape, South Africa. South Afr J Bot 79: 140-147. DOI: 10.1016/j.sajb.2011.10.007. 
van Kleunen M, Dawson W, Essl F, et al. 2015. Global exchange and accumulation of non-native plants. Nature 525 (7567): 100-103. DOI: 10.1038/nature14910.

Vandvik V, Klanderud K, Meineri E, Måren IE, Töpper J. 2016. Seed banks are biodiversity reservoirs: Species-area relationships above versus below ground. Oikos 125 (2): 218-228. DOI: 10.1111/oik.02022.

Vilà M, Espinar JL, Hejda M, Hulme PE, Jarošık V, Maron JL, Pergl J, Schaffner U, Sun Y, Pyšek P. 2011. Ecological impacts of invasive alien plants: A meta-analysis of their effects on species, communities and ecosystems. Ecol Lett 14: 702-708. DOI: 10.1111/j.14610248.2011.01628.x.
Vilà M, Gimeno I. 2007. Does invasion by an alien plant species affect the soil seed bank? J Veg Sci 18: 423-430. DOI: 10.1111/j.16541103.2007.tb02554.x.

Webber BL, Born C, Conn BJ, Hadiah JT, Zalamea PC. 2011. What is in a name? That which we call Cecropia peltata by any other name would be as invasive? Plant Ecol Diver. 4 (2-3): 289-93. DOI: 10.1080/17550874.2011.610372.

Widiyanti P, Kusmana C. 2014. The species composition and structure of vegetation in karst area Gunung Cibodas, Ciampea, Bogor. Jurnal Silvikultur Tropika 05 (2): 69-76. [Indonesian] 